\title{
Discovering the Two Faces of Religious Charismatic Action - Traditional and Modern: A Model
}

\section{Introduction}

In the early decades of this century, Max Weber (1864-1920) identified charisma as a rationalizing force bestowed upon individuals within traditional societies, which gave them and, through them, their followers greater ability to manipulate and control the world. He claimed that charisma was the agent of rationalization, which brought forth the modern, disenchanted world-a world in which mysterious forces no longer come into play. It is a cynical world of instrumental rationality in which, in principle, all things can be mastered by means of calculation. To Weber, this gift of rationality, which in traditional societies is distributed almost randomly, becomes the rightful inheritance of every modern individual. From this perspective charisma, having brought the modern world into being, no longer has any particular function or place in it. It should by all rights disappear.

Weber's approach emptied charisma of content and left it without a locus within which it could operate in the modern age, even though Weber himself saw charisma as vital to meaningful human life. Weber was aware that his concept of charisma was paradoxical, and this led him to have genuine concern for the viability of modern society. Among other places in his corpus, he articulated this in The Protestant Ethic and the Spirit of Capitalism (1905) and in his essay "Science as a Vocation" (1919). Weber feared that life in modern rational society was meaningless or was rapidly becoming so. In it people could no longer be called or swept up by the pulsation of some prophetic pneuma.

The continual stream of new religious movements, as well as political movements, which have sprung up throughout this century may suggest that perhaps Weber was just wrong-perhaps modern religious movements are really possible. Perhaps the search for meaning 
is completely possible now, but merely takes a different form in the modern world. Perhaps today charisma has a different guise, and shows a different face. On the other hand, however, perhaps all these new religious movements merely demonstrate the validity of Weber's perspective, because they are not really "new" religious movements, but only old style religious movements which spring up among traditionally oriented groups which have persisted on the periphery of modern society. What is needed in order to investigate this distinction is a methodology which can identify the characteristics of traditional and modern types of religious action. The presentation of such a methodology is the focus of this paper. First, however, we need to explore whether religion in any form has a future. The following discussion follows Stark and Bainbridge's argument in their book The Future of Religion (1985).

\section{The Future of Religion}

Stark and Bainbridge have argued convincingly for the survival of religion, even in our modern scientific culture. Although they acknowledge secularization as a powerful trend in modern life, religion, as they define it, will not, in fact, disappear. It will not, because it provides answers to the question of the meaning of both life and death. They call the answers to these questions compensators and distinguish them from the rewards which can be provided at least to some people within the structures of everyday life. Thus, they define religions as "human organizations primarily engaged in providing general compensators based upon supernatural assumptions" (Stark and Bainbridge 1985: 8). Their definition of religion is in essential agreement with Daniel Bell's (1977). He defines religion as: "a set of coherent answers to the core existential questions that confront every human group, ..." (Bell 1977: 429).

According to Bell, it is the human predicament that gives rise to religion, not human nature, as the ancient Greeks would have it, nor human history, as Marx believed (1977: 428). Human beings, unlike animals, are conscious of their own death, and this consciousness is integral to the definition of the species-Homo Sapiens "man, the knowing one." The question of salvation is the basic human question, as Weber posed it-"What shall we do, and how shall we live?" (Weber 1958a: 143).

In a sense, it is how one answers this fundamentally religious question that delineates both the structure and content of all human life. Of the five major social institutions, only religion is proper solely 
to human beings. It is our human religious questions and concerns which essentially separate us from animals, and religion is the institution which humanity has devised to deal with them. Therefore, it follows that because these questions will never disappear, neither will religion.

Why then, has the process of secularization been viewed by so many social scientists as the final twilight of the gods (Stark and Bainbridge 1985: 430)? According to Stark and Bainbridge this has occurred primarily for two reasons: first, because they believe that the process is uni-directional and non-reversible; and second, because "they are convinced that a new factor has entered into and canceled the old equation: the rise of science. Science is expected to make religion implausible, and hence modern secularization will not produce new major religions, but an era of rationality in which mysticism can no longer find a significant place" (1985: 430). This position is clearly stated by Anthony F.C. Wallace, who has written: "... the evolutionary future of religion is extinction... the process is inevitable" (1966: 264-265).

Stark and Bainbridge's concept of secularization challenges the uni-directional and non-reversible character of secularization. From their perspective secularization is not a recent phenomenon brought on by the scientific revolution, but is a perennial process in all religious economies. Secularization occurs because the dominant religions, in any culture, are always moving toward an accommodation with the world. They begin in a high tension relationship with the world and move toward a low tension relationship with it. According to them, this process is self-limiting and generates two countervailing processes: revival and religious innovation.

They define revivals as sects which are borm "to restore vigorous otherworldliness to a conventional faith" (Stark and Bainbridge 1985: 2). These sectarian revivals seek to enliven old faiths, while religious innovations are movements which attempt to fashion new religious traditions. Their ability to succeed depends, in part, on the strength and vigor of existing conventional religions to oppose them, and because of their perceived truth. Historically, "thus, did Christianity, Islam and Buddhism, and the other great world faiths wrest dominant market positions from older faiths" (Stark and Bainbridge 1985: 2). They did so, because they were better adapted to the current market demands of their times.

While Stark and Bainbridge acknowledge science as a new and powerful cultural force to be reckoned with, they do not believe that it will eliminated human concern with death or the desire to escape it, or interest in the question of the meaning of life. They do say, 
however, that while "science can challenge some of the claims made by historic religions, ... it cannot provide the primary satisfaction that has long been the raison d'être of religions" (Stark and Bainbridge 1985: 431).

From Stark and Bainbridge's perspective, science only threatens the magical/miraculous formulations which religions offer. While the purely supernatural elements of religion can remain above the fray, any magical formulations which they supply can be directly challenged by science, because magic competes with science in its claim to offer tangible results. Magic claims to utilize supernatural means to provide this worldly ends, while science claim to use this worldly means to achieve this worldly ends. ${ }^{1}$ Since magic and science claim the same empirical playing field, magic is vulnerable to scientific challenge and disconfirmation.

Traditional religions which arose prior to the scientific revolution often included magic in their offering. According to Stark and Bainbridge, this was particularly true for religions that attempted to dominate the religious economy in which they operated. Science, or the systematic process of evaluating explanations empirically, "will always tend to drive out empirically testable explanations that are false or at least less efficient than some other explanation. In consequence, as science is more widely practiced, it will tend to drive out magic" (Stark and Bainbridge 1985: 432). In this way, science creates a cultural atmosphere skeptical of religion.

\section{Effect of Secularization on Traditional Faiths, Sects and Cults}

Stark and Bainbridge see secularization as a circular or perhaps spiral process. Through it "sects are tamed and transformed into churches. Their initial otherworldliness is reduced and worldliness is accommodated. Secularization also eventually leads to the collapse of religious organizations as their extreme worldliness-their weak and vague conceptions of the supernatural-leaves them without the means to satisfy even the universal dimension of religious commitment" (Stark and Bainbridge 1985: 429). This shift in position relative to the larger culture opens the door to the formation of sects, a

\footnotetext{
${ }^{1}$ Religion which uses this worldly and other worldly means to achieve this worldly and other worldly ends is the complex of them all, and this may be why religion is the preeminent human institution.
} 
conservative and circular process, and cults, an innovative and perhaps spiral process.

Within this perspective, traditional religions begin in tension with their surrounding culture and gradually move to a position of relatively low tension with their environment. When the scientific world view became the dominant perspective in Western society, many of the traditional churches, which previously had been in low tension with society, found themselves potentially in higher tension with itthat is, if they held steadfast to certain doctrinal positions such as biblical miracles or the literal interpretation of Genesis. To remain in low tension some of these positions had to be reinterpreted and others had to be abandoned. Today, these organizations, according to Stark and Bainbridge "offer only very weak general conpensators. The conception of the supernatural they sustain has receded to a remote, inactive, almost non-existent divinity" (1985: 434).

Revivalistic sects attempt to restore the vigor and potency of these traditional religions. Evangelical Protestantism and Charismatic Catholicism in the United States are good examples of this effort. While these movements are reasonably successful in attracting and holding members, they have not established a position which makes them invulnerable to the forces of secularization. In fact, "the trouble with revival is that it is heir to a whole cultural history, and this history is replete with defeats of doctrine by science" (Stark and Bainbridge 1985: 435). Their strength may lie more in their strong moral positions than in their defense of supernatural interventions in the world. In any case, in so far as these groups pick and choose between the aspects of the tradition they are willing to defend and those they are not, they have played into the hands of the forces of secularization, with science playing the role of legitimator. Thus, revival, as a response to secularization, is inherently weak and may lack longterm staying power as it speaks to markets already marginalized by secularization.

According to Stark and Bainbridge, innovation may be, therefore, the more fruitful avenue of response to secularization. The faiths that were dominant in the pre-scientific period, were well suited to the cultures in which they arose. They were innovative at the time and did not make claims that were false within the world view of the day. This is no longer the case, as they were not designed to fit the requirements of our present scientific culture. Does that mean, as Brian Wilson suggests, that the development of new religious groups should be seen "as a confirmation of the process of secularization? [and that] They indicate the extent to which religion has become inconsequential for modern society?" (1976: 96). 
For Wilson the emergence of new religions confirms the process of secularization because religious action is essentially traditional and therefore can only develop outside of the impersonal, rational, and bureaucratic framework of modern society. That is to say, according to him, that religious action requires "charismatic leadership, ..., collective behavior, spontaneous faith, and unconstrained obedience" (1976: 125).

While granting that some religious activity in the modern age fits within the traditional framework of action, surely some innovative religion must be modern in character. Stark and Bainbridge suggest Mormonism, the Unification Church, and some older cults, such as Christian Science, Theosophy, the Baha'i, and New Age groups as possible candidates. While they use them as examples of their general contentions that religion remains a viable option in modern society, and that cults tend to flourish in environments where the dominant faiths are the weakest, they don't provide any criteria with which to judge their ultimate success or failure within our current culture or their exactness of fit. Thus, we need to ask, what are the requirements of religious action which would be compatible within the framework of modern scientific society?

\section{A Theory of Modern Religious Action}

Weber's theory of social action is a useful point of departure in order to discover the characteristics of religious action compatible with modern social structure. Two concepts in particular are useful: charisma and prophecy. Charisma because any new structure of religious action requires it; and prophecy because, as Weber said, the construction of a new religion requires a "new and genuine prophecy" (1958b: 155).

Throughout human history the extraordinary and exceptional powers of charisma have provided mankind access to and communication with the ultimate and the sacred. Embodied in an individual leader or prophet who appears to have supernatural and superhuman qualities, charisma orders the world by providing answers to the existential quandary of human life. The answers provide the inspiration for the creeds, the rites, and the institutional forms of religion. However, it was Weber's understanding that in the very process of adapting the extraordinary to the ordinary structures of everyday life, the creative essence of the religious experience is gradually obscured and eventually obliterated. This dimming of the vision of the prophet over time leads to a crisis of meaning for the group or the 
community involved. The sense of distress which inevitably develops can only be addressed, within his theory, by the emergence of another prophet or charismatic leader. It is this evolutionary cycle which, Weber theorized, is the vehicle of change within traditional societies. In it each successive charismatic vision, in order adequately to resolve the new or existing level of distress, is more rational than the last, until in the end the world is totally rationalized.

As we have seen, modern Western society from Weber's point of view is such a society. Charisma, the dynamic principle of change in the process of rationalization, appears to have no place once society has become rationalized. Charisma once routinized, the unique once made uniform, seems to free man from his dependence upon the gift of charisma, and seems to give man a sense of independent action and freedom of control. And yet even Weber saw that rational action, a by-product of the unique and superhuman quality of charisma, was in truth only a pale imitation or shadow of charisma. Thus he felt that for social life to be human and to have meaning, it must contain the quality or at least the possibility of charisma. ${ }^{2}$ It is this alternative conception of charisma, as the essence of foundation, which Weber recognized as so important, that can be useful in the construction of a model of religious action in the modern age.

The system of authority which Weber identified as modern is rational-legal or rational-bureaucratic. This type of social system is characterized by its impersonality. In it there is little room for the individual creative action so necessary for personal charisma, and rationality rather than affectivity governs the conduct of action. Although Weber correctly observed the shift in the framework of legitimacy in a system of rational legal domination from that of a per-

${ }^{2}$ Both Parsons and Mommsen have made the observation that for Weber charisma provides the basis of legitimacy in any social system traditional or modern. (Williams-Hogan 1985: 637) As Parsons says; "In other words, charisma is directly linked with legitimacy, is indeed the name in Weber's system for the source of legitimacy in general." (Parsons 1968: 663) Mommsen says; "Although Weber treated of charismatic leadership in the context of his political sociology as just one paticular type among others, he nonetheless showed a strong tendency to identify it with genuine leadership of any kind ... The notion that all genuine leadership is, in some way or another, of a charismatic nature does indeed lead to the conclusion that some element of 'charisma,' whether in a routinized or in a disguised form, is required in every system of domination, regardless of its particular nature." (Mommsen 1974: 79) "The essential point is that the quest for the source of legality always leads back to a charismatic, whether by apostolic succession, revealed law (Calvin's Geneva), divine right or general will." Parsons 1968: 665. 
sonal order to that of an impersonal one, he continued to imagine that charismatic breakthroughs, if they were to be possible at all in modern societies, would still be embodied in personal charismatic leaders. That is, although Weber understood the tremendous structural changes wrought by the coming of modern society, he never gave up the prophet as the model of charisma.

The difficulty with this model is not merely theoretical. Although modern man continues to be fascinating by personal charisma which bursts into his rationally ordered world from time to time, it also frequently fills him with a sense of horror and dread, on the one hand, and on the other, with a sense of the ridiculous and the absurd. ${ }^{3}$ Reactions to the awesome "demonic" powers of Hitler, Stalin, and Jim Jones exemplify our collective sense of horror, and reactions to the salvatory claims of the tele-evangelists exemplify our sense of the ridiculous. What this discussion suggests is, that while the concept of charisma as a source of inspiration and legitimation can be retained as a theoretical element, it would be fruitful to look for its location elsewhere than in the individual.

But the question of where else to look presents a serious problem. For as we know a "new religion" requires " a new and genuine prophecy," and what other source of prophecy is there but the prophet? Obviously, there is none. However, while it is necessary to acknowledge this truth, the specific nature of the prophetic role remains open, thus indicating an area in need of development.

How to conceptualize the prophetic role is the key to understanding the modern face of charisma. If the role of the prophet changes, so then do the other elements of religious action. In the traditional framework of action the prophet has a very personal role to play. His followers develop a very close relationship to him, and he demands absolute obedience to the religious law. In this model, in an extreme case charisma can be transformed into Franz Neumann's concept of Caesarism where power not love rules (1962: 246). If however, the prophet, but not his words, were absent from the founding and the unfolding of a religious movement then the whole framework of action which could develop would be different.

\footnotetext{
${ }^{3}$ It should be noted that in men like Martin Luther King, Jr, and Ghandi it still retains its traditional pull. Whether such men can "call" both traditional and modern segments of present day society is a question that is addressed later in this paper.
} 


\section{Two Faces of Charisma: Traditional and Moderm}

Within the traditional framework of action, the problems which the prophet addresses are socio-historically specific and primarily communal, and the solutions offered are in the nature of a collective covenant. That is, they will resolve the problem only if they become binding on the group as a whole. The laws or rules which form the new way of life or the new covenant are promulgated to correct lapses in the social structure, not necessarily lapses of the individual. As a result, they are to be enforced by the group not merely by the individual. Thus acknowledgment of the charismatic quality of the prophet requires in itself spontaneous obedience to his demands. If we abstract these characteristics, we can present a more detailed model of traditional prophecy, which focuses on its structural components:

1. Mode of Prophecy: oral. 2. Nature of Crisis: communal. 3. Nature of Covenant: collective. 4. Nature of Message: particularistic. 5. Nature of Controls: external. 6. Nature of Response: demanded obedience; spontaneous obedience; group directed subordination.

In examining traditional prophecy from a structural perspective, it becomes clear that modern individuals will not heed its call. If they could hear any calls to meaning, or the call to resolve the existential human question, it must be in a form that is congenial to the requirements of modernity. What follows is the proposed model of modern prophecy: 1. Mode of Prophecy: written. 2. Nature of Crisis: personal. 3. Nature of Covenant: individual. 4. Nature of Message: universal. 5. Nature of Controls: internal. 6. Nature of Response: voluntary obedience; reflective obedience; self-subordination. ${ }^{4}$

For the sake of clarity, it might be useful to present the two models in a schematic form.

\footnotetext{
${ }^{4}$ After this paper was presented at the IAHR Conference in Turku, Finland, August 4-7, 1997, Matti Kamppinen from the University of 'Turku suggested including an additional component namely, the scope of control of the prophetic leader. Does it reach into all aspects of the followers life, both public and private, or does it permit areas of individual discretion and action? Thus, is the scope of control broad or narrow? This suggestion is useful and a real addition to the model. How this would play out in the model of modern religious action where the emphasis is on self control remains to be explored.
} 


\section{Two Models of Prophecy}

Category

1. Mode of Prophecy

2. Nature of Crisis

Category

3. Nature of Covenant

4. Nature of Message

5. Nature of Controls

6. Nature of Response
Traditional

oral

communal

Traditional

collective

particularistic

external

demanded

obedience
Modern

written

personal

Modern

individual

universal

internal

reflective

obedience

\section{Model Categories}

1. Mode of Prophecy. This refers to form of communication by which the prophetic message is received. A revelatory experience of an individual is the starting point of the social phenomenon of prophecy. However, regardless of the nature of that experience, it must be communicated to others if it is to have any social significance. Whether that experience is communicated by speech or written word is of tremendous importance in the subsequent development of prophecy. This will be discussed in greater detail later.

2. Nature of Crisis. This category refers to the type of situation which calls forth the prophecy and the response. Communal crises affect the well-being of a group of people and often are situations which directly affect the group as a whole. Both the cause and the solution of a communal crisis are felt to be a communal matter, and communal action is necessary for its resolution. Examples of communal crises are: wars, famines, pestilence, oppression, and economic and social dislocation. Personal crises, however, are private, and while they reflect concerns that many individuals actually have, they are experienced primarily within the self. The resolution of personal crises requires action on the part of the individual. Examples of personal crises are: fear of death, sense of personal sin, anxiety about the meaning of life, and the search for God.

3. Nature of Covenant. A covenant or a Berith, is an agreement between persons or parties. It is also defined in Webster's New Collegiate Dictionary as, "a solemn compact between members of a church to main tain its faith, discipline, etc..." (Webster's 1958: 192). Yahweh made a covenant with the children of Israel, and for the covenant to be maintained by "the chosen people" each and every member was 
required to live according to His law. On His part, Yahweh promised his people that they would live long and well in the promised land if they abided by the covenant, that is if they obeyed his law. This identifies the nature of a collective covenant. It is a compact which is binding on all the members of the group. When God offers man an individual covenant, however, each man is bound by God's law independently. Ultimately, he is solely responsible for his own conduct. Jesus, when he instituted the holy supper said, "This cup is the new covenant in my blood, which is shed for you." (Luke 22:20) That this new covenant was between God and each man is apparent in the Lord's saying: "He who believes and is baptized will be saved; but he who does not believe will be condemned." (Mark 16:16)

4. Nature of the Message. What is the message about, and to whom is it addressed? Is the prophet speaking to a very particular situation, which is affecting a very specific people, and which cannot easily be generalized? Or is the prophet speaking to the conditions and concerns of all people everywhere? Is the message (and the solution it entails) bound by class, social, and historical issues, or is it like a scientific formula, usable and replicable regardless of the specifics of time and place? If the message cannot be generalized, it is particularistic. If it is like a scientific formula, it has universal applicability.

5. Nature of Controls. Any compact or agreement requires a system of sanctions to ensure compliance with it. This category refers to the way in which the covenant is enforced. It can either be enforced through the external supervision and control of others, or it can be enforced through internal controls or self discipline. A contrast can be made here between a system where the community has the legitimate right to oversee the spiritual progress of all of its members, and where one's spiritual progress is confessed only to God.

6. Nature of Response. This concept refers to the expectations that the prophet has regarding those who receive his message. Must they respond to the demands of his message completely, automatically, and without question, because he or his disciples say so; or are they permitted to reflect on his message, to see if it makes sense, and then to choose voluntary to subordinate themselves to it? Must those to whom the prophet is sent respond enthusiastically and spontaneously, or may they think and reflect on the message? 


\section{Distinctions}

With this brief discussion of the terminology used in the model, it would now be useful to probe the categories more deeply, particularly the distinction between oral and written prophecy.

\section{Oral vs. Written Prophecy}

In his book Beyond the Written Word, William A. Graham quotes the Egyptologist Alan Gardiner who said: "Speech and Writing have been the two main stages passed by [man] on his long road to civilization" (1987: 12). They may also define two fundamentally different models of prophecy. In fact, the difference between oral and written prophecy may be the key distinction between the structures of traditional and modern prophecy, because the other distinctions between these models appear to follow from it. Oral prophecy, almost by definition is, in its founding stage, communal. While access to written communication, according to Graham, "is through an individual's private, silent reading and study," (1987: 9) the written word has gradually opened "new vistas on both the substance and shape of knowledge" (1987: 14). The spoken word stimulates our affections, while the written word encourages critical reflection. ${ }^{5}$ Graham continues:

Still more: the use of written records eventually stimulates or coincides with new concerns and purposes for verbal narrative that are qualitatively as well as quantitatively different from those of primary oral cultures. Speaking involves interaction with an audience; writing necessitates distancing of the writer from his or her reader. The inclination of modern hermeneuts such as Paul Ricoeur to see the written text as utterly independent of its author is an extreme but logical expression of the autonomy of the written word. Fixing a text visually objectifies its discourse as symbols on the page and makes it as something abstract and impersonal, an object of analysis apart from the specific, always

\footnotetext{
${ }^{5}$ As any lover knows, hearing the voice of the loved one brings a welling up of affection that merely seeing the name does not. And as Jack Goody says, “... writing, and still more alphabetic literacy, made it possible to scrutinize discourse in a different kind of way by giving oral communication a semipermanent form; this scrutiny favoured the increase in scope of critical activity ... writing laid out discourse before one's eyes in a different kind of way ... Graham 1987: 15.
} 
contextual situations of oral speech... literacy makes 'study' possible, and with it, the 'abstractly sequential, classificatory, explanatory examination of phenomena or of stated truths' that is 'impossible without writing and reading (1987: 15).

However, not only does writing change the processing of information; it also affects the manner that it is used. For example, as Graham says:

oral retelling of the past, even by specialized guardians of a society's traditions, is not subject to the same repeated scrutiny over time (whether within a single transmitter's lifetime or over several generations) that a written record receives. Where the former is personal (which is to say, communal, in the most immediate sense) and directed to present concerns and situations, the latter has existence apart from its author, his or her 'present' concerns, and those of the community, which will rarely be the same as those of a latter time (1987: 16). ${ }^{6}$

Written communication has the capacity to change both the transmission of culture and an individual's relationship to his own past. It allows the past to become fixed and distant from the present, but it also allows it to be a permanent possession, unlike the ephemeral quality of an oral presentation. Furthermore, speech has a different audience with different demands than does the written word. What one hopes to find in a text differs markedly from one's expectations of a performance. Thus, in Graham it is argued that "the graphic representation of speech ... is a tool' that 'encourages reflection upon and the organization of information' and 'also changes the nature of representations of the world' even for those in the culture who cannot write" (1987: 17).

This discussion has tremendous significance, because currently we live in an age of the written word. As Graham says:

For most if not all of us, the fixed, visible page of print is the fundamental medium of both information and demonstration of

\footnotetext{
${ }^{6}$ Further, as Goody and Watt say, "In oral societies the cultural tradition is transmitted almost entirely by face-to-face communication; and changes in its content are accompanied by the homeostatic process of forgetting or transforming those parts of the tradition that cease to be either necessary or relevant. Literate societies, on the other hand, cannot discard, absorb, or transmute the past in the same way. Instead, their members are faced with permanently recorded versions of the past and its beliefs; and because the past is thus set apart from the present, historical inquiry becomes possible." Graham 1987: 16.
} 
proof. If anything is truly important, we have to 'get it in writing,' be it an idea, a report, a directive, or an agreement. We want tangible evidence of 'documentation'; we need things of importance 'signed and sealed.' To a degree unknown in any other culture in history, knowledge for us is 'book-learning'; and no orally communicated word carries the kind of legal, scholarly, or administrative authority for us that a written or printed document does (1987: 9).

For the purposes of this paper, one could argue further that oral prophecy in such an age, even though it continues to exist, cannot carry the same authority as written prophecy. A "book religion" or prophecy communicated in a book would appear to be more congenial to the spirit of the age.

\section{Communal vs. Personal Crisis}

Identity and purpose are essential characteristics of truly human life. These characteristics are not given at birth but must be socially acquired in an interactive process between the person and his community. In traditional societies one's identity and commitments are primarily defined by the community and are communal in nature. In such societies, according to Phillip Rieff, the process of socialization or civilization require "the submerging of their individualities within a communal purpose" (1968: 10). In these societies what constitutes a crisis of action is a breakdown of either the efficacy of the communal formula for living (prescription for life) itself, or a substantial reduction in its implementation by the people. The duty of the prophet in such situations is to recall or remember and possibly redefine or extend the communal purposes and vision so that the members of that community can re-identify with its aims. As we have seen, in Weber's view, the unfolding of this process within the JudeoChristian tradition gradually led to the rationalization of the world.

\footnotetext{
${ }^{7}$ Two problems need to be touched on here. The obvious fact that oral prophecy continues to thrive among certain groups who live in modern society; and the fact that written prophecy does not appear to share the same type of authority as do legal, scholarly and administrative spheres, even though theoretically it should. These things can be partially explained by the modern rationalists who treat religion as irrelevant and the parallel assessment of the romantics that it is essentially a non-rational phenomena. This explanation draws on an understanding of the romantic reaction to the Enlightenment.
} 
As he said, "The rational conception of the world is contained in germ within the myth of the redeemer" (Weber 1958a: 274). In the rationalization of the world the institutional areas of communal life became increasingly specialized and rational. As Luckmann explains:

The functionally 'rational' norms of institutions characterized by a complex division of labor and specialization of roles became increasingly disengaged from the biographical context of meaning in which institutional performances stood for the individual performer (1967: 97).

In modern society institutional performances no longer stand for the individual and no longer bind and express the identity of the individual. The smooth and rational functioning of the external and objective institutional order of society does not require that its functioning have subjective significance for the individual. The institutional order is concerned only with the performance, as such, and not with the individuals subjective biographical context. Again, as Luckmann says:

In comparison to traditional social orders, the primary public institutions no longer significantly contribute to the formation of individual consciousness and personality, ... Personal identity becomes, essentially, a private phenomenon. This is, perhaps, the most revolutionary trait of modern society. Institutional segmentation left wide areas in the life of the individual unstructured and the overarching biographical context of significance undetermined (1967: 97).

In this process emerged the private or personal sphere, in which the individual has a sense of freedom and autonomy. It is within this sphere or domain that purpose is now defined and identity is acquired. This personal sphere has become the arena in which the inevitable human quest for ultimate meaning takes place. Because meaning is now personally defined, crises in meaning are personal rather than communal. And it is precisely crises within this area that modern prophecy should address, if individuals are to find a religious vision which is relevant to their lives. Modern prophecy must address these issues if individuals are to be able to respond to it, but it must also provide a new form of integration or relationship between the subjective and objective worlds. It must be capable of addressing personal concerns and crises in a way which also recognizes the dual quality of human nature which is both personal and communal or individual and collective. In the modern age a genuinely new prophecy would deal with both because, while meaning may be essentially 
a matter of personal definition, the communal aspect of human life requires that not all the vital human functions be left in the hands of individuals to shape according to merely personal whim or fashion. A genuine new prophecy would not only give comfort in the face of personal crisis, it would encourage communion.

To a certain extent religious institutions in the modern world have attempted to re-fashion their messages to conform to this demand for personal solace. But today secular faiths or secular therapies compete with the Christian communions to provide the techniques of comfort and solace as men and women search for meaning in pianissimo. Weber saw the danger in intellectually constructing new religions without new and genuine prophecy, whether these constructions were attempted within the old churches or within the academic community. According to him, such attempts would only create monstrosities. While it may be true that currently many prophetic monstrosities may exist, this should not prevent sociologists from taking up the challenge of recognizing new prophecies in whatever form they take, even if they should occur in a disenchanted world.

\section{Collective and Individual Covenants}

According to the Oxford Dictionary of the Christian Church, a covenant is "a bond entered into voluntarily by two parties by which each pledges himself to do something for the other." (Cross 1957: 350) The religious history of the West is a history of covenants. The old covenant was between Yahweh and the people of Israel. He was the sovereign and Israel the servant, in a manner similar to the ancient Near Eastern suzerainty treaty pattern. The Sinai story follows this treaty pattern (Ex. 19-24) which has the following elements, according to J. Arthur Thompson:

1) there is a recital of God's acts prior to the making of the covenant (Ex. 19:4);

2) followed by the call to enter into a covenant and to obey. The stipulations in the form of the Decalogue are give in Ex. 20 and supplemented by other laws (Ex. 21-23);

3) There is a reference to the oath that Israel took (Ex. 19:8;24:3);

4) and to the religious ceremony at which the covenant was ratified (Ex. 24:4-8);

5) Curses and blessings are contained in the Decalogue (Ex. 20:1$17)$; 
6) and there is mention of a covenant document (Ex. 24:7) (Thompson 1979: 792).

Covenants are initiated by God. They contain promises that are everlasting. God will remember them and will confirm them with a sign. What was expected in return was obedience on the part of Israel. Obedience was not considered a condition of the covenant but was rather a definition of the appropriate relationship between God and his people, because the covenant identified the form through which the people of Israel could achieve genuine humanity. "There could be no blessings or fellowship without obedience" (Tompsom 1979: 792). Within this relationship Israel was expected to "keep the covenant, to "remember" it, to "do" it, and to "walk in" it. Her repeated failure to do so resulted in curses. "Hence ... she experienced ... natural calamities, war, sickness, exile, and death, whereas had she kept the covenant she might have enjoyed the blessings of the covenant instead (Lev. 26; Dt. 27-28)" (Tompsom 1979: 792).

In the Old Testament it is made clear that God's promises are eternal and that they establish the structure of human well-being. $\mathrm{He}$ is faithful. He keeps his Word, but the people do not. The role of the prophets was to call the people to renew their commitment to the covenant. Sawyer informs us that Prophets are "proclaimers" and "predictors." (1987: 1) They are spokesmen for the Living God and they declare his truth. They declare that in his Word or in his truth is found the way of life, and that all other ways lead to death. Following God's Word is good and leads to good, disobeying his Word is evil and leads to evil. Their predictions flowed from this reality. If Israel breaks the covenant, then curses or evil are the inevitable result. But "the promise of God could not fail," even if Israel did (Thompson 1979: 792). As Jeremiah and other prophets predicted, if Israel should fail, God would make a new covenant (Jer. 31:31-33).

There would be a remnant in whom, by way of judgment and repentance God would honor His promises. He would make a new covenant, not new in essence, but new in fulfillment. His law would be written on hearts of flesh (Thompson 1979: 792).

The words of Jeremiah point to a more internal or ethical covenant. In the life of Christ, the Messiah and Redeemer, this new covenant is established. This new covenant is more spiritual, unlike the Decalogue inscribed on tablets of stone. McCaig states that "Its re-

\footnotetext{
${ }^{8}$ The elements of this pattern have been placed in numerical order for the convenience of the reader.
} 
quirements are not simply given in the form of external rules, but the living Spirit possesses the heart; the law becomes an internal dominating principle, and so true obedience is secured" (McCaig 1979: 796). The new covenant does not replace the law, it gives it genuine life, and in contrast to the collective covenant between God and Israel, Christ offered every individual the possibility of making a covenant with him. During the last supper he said, "This cup is the new covenant in my blood, which is shed for you." (Lk. 22:20) The promise of the new covenant was eternal life, the path to which was repentance and the remission of sins through the blood of the new covenant. This is the message that the disciples were to preach in his name to everyone in all nations.

Christianity grew around the worship of the risen Lord-the God of eternal life. Each man could find eternal life if he would repent and take the sacraments in the name of the Lord. Although the commemoration of the last supper was a communal ritual of the early Christian community, eternal life was promised to individuals. However, as the Christian church grew and eventually adopted the formula that there could be no salvation outside of the Church, it appeared as if the covenant was between the Church and God, rather than between each individual and God. Attempts to reform Christianity frequently resulted in the development of Covenant Theologies which were conceived of as identifying the compact between God and his elect. This covenant was a covenant of grace requiring only faith on the part of believer. In taking away the believer active role in the preservation of the covenant, the ultimate role of the covenant in religious life was thrown into doubt. The Enlightenment then cast doubt on the efficacy of the religious enterprise itself. Because it appeared that rationality could completely destroy religion if its relevance was asserted to be primarily in the external/empirical world, or the world of action, during the romantic reaction, religion became an affair of the human heart. No longer covenantal in nature, religion in the modern age, according to Rabbi Harold Kushner, exists "not to explain God or to Please God, but to help us meet some of our most basic needs" (Neuhaus 1989: 52 ).

Modern prophecy within the Judeo-Christian framework, if genuine, would re-establish a covenant between God and man. Such a covenant would call the individual to respond freely to the rational Living Word of God. 


\section{Particularistic and Universal Messages}

The structure of modern society is dependent upon universalistic norms. As Parsons has pointed out:

Although many of the elements of such a general normative order appeared in quite highly developed form in earlier societies, in my view their crystallization into a coherent system represents a distinctive new step, which more than the industrial revolution itself, ushered in the modern era of social evolution (1982: 316).

It is evident that all the major social institutions have been substantially altered by this step to establish a general normative order. Politics and economics are perhaps the two most obvious examples. This is indicated by the development and globalization of the European nation-state and its law, and the development of international markets and money economies. According to Parsons the development of a general legal system is central to the process of societal evolution. He states:

A general legal system is an integrated system of universalistic norms, applicable to the society as a whole rather than to a few functional or segmental sectors, highly generalized in terms of principles and standards, and relatively independent of both the religious agencies that legitimize the normative order of the society and vested interest groups in the operative sector, particularly in government (1982: 316).

Nonetheless, education and the family have also undergone dramatic changes, with the development of universal education and the nuclearization of the family. Standardization in technology and the development of the scientific method are also noteworthy examples of this change.

The institution of religion is the one major exception. It is precisely the failure of religion to universalize at the normative level that has lead to the current questioning of its relevance. While at the organizational level religion has become increasingly bureaucratized in the modern era (a key element of universalization), normatively, religions have either tended to remain particularistic or have liberalized. These two tendency are in opposition to one another and compete for recognition on the same plane of social reality. Thus, the relationship between religion and modernity has become politicized, as the advocates of the contending positions desire (or demand) the exclusive right to define that relationship. From those who hold the particularistic perspective, modernity is viewed as a threat to religion, and 
while they retreat from it in order to preserve the substance of religion, they invalidate modernity itself. On the other hand, the liberals, in their rush to embrace modernity, must of necessity invalidate many particular religious ideas, and in doing so frequently invalidate the fundamental premises of the religious world view.

Liberalization has not provided the key to the universalization of religion because conceptually, even though it has attempted to have a broad appeal by negating particularism, it does not represent a higher or deeper level of religious understanding. The achievement of a new level of understanding is a necessary prerequisite of universalization. Rather, the liberal perspective comes from adopting natural empiricism as the universal standard of truth. Naturalism cannot be the universal form of religion. It does not represent a penetration of religious reality, but its denial. Furthermore it does not represent an overcoming of religion, only its abandonment.

Rationalization and universalization represent processes that discover truths that integrate diverse and divergent particulars at a deeper and more general level of reality. It is for this reason that they are more broadly applicable. The universalization of the JudeoChristian tradition would not lead to its abandonment, but would entail the discovery of a more interior appreciation of its truths. It would lead to the development of a perspective that could explain the apparent surface contradictions of that tradition in a consistent and rational manner, without at the same time invalidating the truths inherent in other religious traditions.

Genuine modern prophecy would minimally provide a new and more universal ethic, providing deeper insight into the question, "who is my neighbor?" This would de-mystify the sacred. Furthermore, genuine modern prophecy would provide new insights into the four area of the global-human condition identified by Robertson and Chirico: "namely, societies; individuals; the system of societies; and (in the generic sense) mankind" (Beckford and Luckmann 1989: 11).

If religion is to reclaim its relevance for modern individuals and modern societies, it must be able to address substantively within its own appropriate sphere the universal concerns of modernity.

\section{External and Internal Controls}

For visions to live and structure the lives of men, specific means must be used to encourage adherence and to control deviance. These visions live in appropriately socialized human beings. Prior to the completion of the initial socialization process human behavior is con- 
trolled primarily by others. Once socialized, human beings have the capacity to sanction or control their own behavior. All societies use both external and internal mechanisms of social control. As sociology understands the concept of social control, according to Berger, "it refers to the various means used by a society to bring its recalcitrant members back into line" (1963: 68). Societies employ a great variety of mechanisms of control, depending upon the social situation involved. They use "deterrents, incentives, rewards and punishments" (McGuire 1987: 241). However, the mechanism of control found in traditional societies, in general, tends to be more external and physical than are the mechanisms of control in modern societies. Furthermore, in traditional societies the whole community is the agent of control. In modern society, the self becomes the fundamental agent of control, utilizing essentially internal and psychological means. However, the impersonal structures of modern institutions, such as the state and market, also serve as agents of control. These institutions do utilize psychological mechanisms of control, but they also have at their disposal a broad range of physical and economic tools.

Socialization in traditional societies is status-centered, while modern socialization is person-centered. In traditional societies the individual must acquire a status which has been defined for him by the community to be considered truly human. In modern societies the individual is given the responsibility of placing himself and developing his own humanity. Therefore, it makes sense that in societies where the power to place is in the hands of the community, the community also has the primary power to shape and control, and conversely, in societies where the power to place is in the hands of the individual, he is socialized into the power of self-control.

The status positions in traditional society are hierarchically organized. Respect and deference follow from one's position in the hierarchy-the higher the status position, the greater the respect due. Traditional societies emphasize obedience, conformity to rules, and respect for authority. The socialization process is organized around the maintenance of social solidarity. Since the value of maintaining the social order is believed to be self-evident, the demand for obedience to any particular command require no justification.

Even though status positions in modern society are still hierarchically organized, the individual's relationship to them is fundamentally different. $\mathrm{He}$ is no longer given a place in society, but must choose one. Thus, the socialization process emphasizes mechanisms of control that will both aid the individual's ability to choose and encourages his commitment to his choice. The individual is asked to understand and question both his own motives and feelings, and the 
reasons why society is structured the way it is. A critical approach to both self and society is encouraged in the name of "higher" ethical and rational principles. The individual is encouraged to explore why he acts the way he does, and the society and its agents are encouraged to explain why it makes the demands it does. In traditional society the order of life is given, and the individual must fit himself into that order; in modern society the order of life is created in a dialogue between the individual and the other individuals and collective agents of that order.

\section{Demanded and Voluntary Obedience}

It follows therefore that once the possibility of internalized selfcontrol became the dominant model of social control, externally enforced mechanisms of communal control appear to have lost their primacy. ${ }^{9}$ While it is true that there are prophetic movements in the modern age that have continued to operate within the framework of externally imposed controls, their long term efficacy is in doubt. ${ }^{10}$ Once individuals have experienced self-control, they may only be able to respond to prophecies that welcome self conscious participation in its realization.

\section{Utility and Evaluation}

Weber's approach emptied charisma of content and left it without a locus within which it could operate in the modern age, even though Weber himself saw charisma as vital to meaningful human social life. $^{11}$

\footnotetext{
${ }^{9}$ Social order in modern society is based upon the internalized control of its members. The break down of these internalized controls often leads to behavior which requires intervention of an external system of control e.g. the legal system.

${ }^{10}$ Witness the collapse of communism in Eastern Europe.

${ }^{11}$ Weber was aware that his concept of charisma was paradoxical. This led him to have a genuine concern for the viability of modern society. As he said in The Protestant Ethic and the Spirit of Capitalism: (1958b: 182) "For of this last stage of this cultural development, it might well be truly said: 'Specialists without spirit, sensualists without heart; this nullity imagines that it has attained a level of civilization never before achieved." It should be pointed out that in holding this position, Weber was not alone among
} 


\section{Charisma}

In traditional society the charismatic personality or the prophet brought a universalizing and rationalizing message which simultaneously expanded and penetrated the sphere of external order in the world, giving people the ability to manipulate and control the natural world. The disenchanted world is the end product of this process, when no more mysterious forces come into play, and when one can in principle master all things through rational calculation. The gift of rationality almost randomly bestowed in the ancient world becomes, for Weber, the rightful inheritance of the modern individual. Clarity brought by charisma in a dark and foreboding world looses its brilliance and its ability to beckon when the world is filled with light. As Weber portrays this brave new world of light, however, he speaks of an iron cage and the images are hard and cold. What is missing in this Arctic world of rationality and light is meaning and warmththe genuinely human, or in Weber's terms the 'highest cultural and spiritual values."

In investigating charisma in only traditional societies, Weber saw charisma as one dimensional, solely as the force of rationality. So envisioned, charisma dissipates in the very act of realizing itself through the transformation of the world. Given Weber's analysis, therefore, one would not expect to find genuinely new religions emerging within our transformed and rational modern society. Yet this is what occurred in the founding of the General Conference of the New Church in Great Britain (1787) (see Williams-Hogan 1985). ${ }^{12}$ In the examination of the founding something that is best identified by the sociological term charisma, though obviously in modern guise, is clearly evident. This points to the possibility that charisma is not static but has the dynamic capacity to be responsive to the structural characteristics of the society in which it operates.

According to Weber, the essential characteristic of charisma is its ability to set something apart from the ordinary, and thus, it is

nineteenth-century social theorists. For example, the Italian Vilfredo Pareto is another who shared this perspective.

12 In an unpublished follow-up study entitled "Charisma in the Modern World: A New Theory of Religious Action" (Williams-Hogan 1990), the characteristics of this group are examined and are determined to fit the model of modern religious action. In this earlier study the model presented here in this paper is applied and tested on the General Conference or the Swedenborgians, the Quakers, the Shakers, and the Methodists. All of these groups have at least some characteristics which are identified as modern. 
treated as "endowed with supernatural, ..., or exceptional powers or qualities" (1964: 358). "Setting apart from the ordinary" in modern rational bureaucratic societies will obviously have a different form than it would in traditional societies. Thus, perhaps charisma has not been dissipated in modern society as Weber thought, but has merely been transformed. However, because of this change of form, initially it would be difficult to observe.

In order to conform to the structural requirements of traditional society, genuinely new, rational and universal insights are best articulated within the affective and spoken pronouncements of a personal prophet; while in modern society, it would seem that what is genuinely new is a deeper penetration and appreciation of what is good, which is best discovered through the rational form of the written word. ${ }^{13}$ Charisma is that quality which makes visible the extraordinary and the supernatural in any context. In traditional society, rationality, or what in those societies was extraordinary could only be appreciated, and responded to, when it was presented in the affective form of the charismatic prophet. In modern society, spirituality, the truly human, or what to us is extraordinary can only be appreciated and responded to when presented in the rational form of the charismatic book Charisma, thus, must be actually bi-polar in nature, always providing the balance necessary in the quest for salvation in any age.

Sociologically, charisma is the vital ingredient of religious action. It calls men to act. It does so, because in every age it provides all who are seeking salvation the very thing they cannot provide for themselves, either a vision of the true or a vision of the good. Charisma is recognized whether in the prophet or in the book, because it points to what is missing when we ask, "what shall we do and how shall we live?"

\footnotetext{
${ }^{13}$ Emanuel Swedenborg (1688-1772) highlights in his Arcana Coelestia why he thought a new revelation in a new form was necessary: "At the present day the doctrinal things of love to the Lord and of charity to the neighbor are rejected, ... and thus are so completely lost that there remains scarcely any trace of them" (Swedenborg 1998: number 3419) Swedenborg's religious writings were the source of the new vision of the General Conference founded in 1787. Thus, both their doctrine and their process of formation reveal modern elements.
} 


\section{Prophecy}

In moving beyond Weber's one dimensional conception of charisma as a rationalizing force located in the prophetic personality, to seeing it as having the additional capacity to be a humanizing force located in the prophetic book, we have also had to move beyond any model of prophecy which identifies the interactive relationship between the prophet and the people as the key element of prophecy. While it is clear that prophecy requires acknowledgment by others, if it is to be realized and be a force in the world, that acknowledgment can occur during quiet moments of reflective reading, as well as in the highly charged atmosphere of a revival. As it has been argued here, the modern individual is more likely to discover ideas which will guide his life during quiet, reflective reading than through his being sweptup in the emotional contagion of a mass religious movement. Thomas Overholt in his most recent book, Channels of Prophecy, argues for the continual possibility of prophecy in the modern world. While he identifies "feedback from the audience" as the key element of prophecy, (which, if it were absent would bring prophecy to an end) he expands his conception of prophecy in the present day to include prophetic institutions, ordinary people and prophetic books (Overholt 1989: 158, 165-174). While his use of the word "audience" remains a barrier in the discussion of modern prophecy because it implies that the prophet and the people are consciously present to each other, his overall presentation is supportive of the model of modern prophecy presented here.

\section{Commentary on and Evidence of Modern Prophecy}

In the chapter in which Overholt argues for the current possibility of prophecy in Western society, he draws on the work of other commentators to support his claim. He also examines a recent prophetic book and the phenomenon of channeling. He refers to the work of Hanson, Tucker, Ramsay, and Hall among others. He finds Hanson useful, because he acknowledges the existence of prophetic "activity" today, although he is not specific about the manner in which it appears. Tucker no longer finds that "activity" in the role of the individual prophet, but in the people who constitute the church. Those in the church must be open to the guidance of the prophetic words found in the Bible and must allow them to consciously shape their understanding of the present and their vision of the future. "In a word, 
they must do corporately what the biblical prophets did individually, namely, interpret present events in terms of the theological traditions in which they stand" (Overholt 1989: 165). This understanding of prophecy simultaneously acknowledges the vital and on-going social role of prophecy, while recognizing the problematic nature of individual prophecy in the modern world. However, locating prophecy solely in institutions blunts its transformative character, which has been one of its most salient features.

Ramsay does not have a problem in identifying specific persons who he claims are twentieth century Christian prophets: Walter Rauchenbusch, Martin Luther King, Jr., Gustavo Gutiérrez, and Rosemary Radford Ruether (Overholt 1989: 166). Since for Ramsay, prophets are simply those who speak forth for the living God, there will be prophets in any age. They will be recognizable because their messages will be consistent with the Scriptures. "Since the Spirit is not going to contradict what the Spirit has already inspired in the Scripture," the Bible provides us with a method of assessing prophetic activity, even in the twentieth century (Ramsay 1986: 2). Ramsay finds the key to modern prophecy in God's demand for social justice as exemplified by the Old Testament prophets. Each of the individuals which he discusses in his book has called for social justice, each for a different oppressed group-the American working class, American blacks, Latin American peasants, and women. $\mathrm{He}$ readily admits that not everything written by these "prophets" is true and that they do not all agree. Thus, he invites his own readers to make their own judgments, using the church's canon of authentic prophets as the guide. Although Ramsay's work focuses on God's mission as primarily temporal in the form of social justice, nonetheless it provides several useful ideas about modern prophecy: first, it is likely to be in written form; second, it must be consistent with the Scriptures; and third, it is the individual through reflection on the Scriptures and the "prophecy" who must weigh its authenticity. While consistency with the Scriptures does not necessarily suggest the universalization or deepening interpretation of past revelation which the new model suggest, nevertheless such an idea implies rationality and resonates with the concept of universalization.

Hall in a work entitled, Anyone Can Prophesy, democratizes prophetic activity. Like Ramsay, he assumes a living God who is constantly providing for his people. Prophecy, personal guidance and preaching are some of the means He uses to care for us. Prophecy is distinct from both personal guidance and preaching. He understands prophecy to be "God speaking through us" to others, while in personal guidance $\mathrm{He}$ speaks specifically to the individual, and in preaching 
the preacher speaks to us about God in his own words (Overholt 1989: 168).

From Hall's perspective prophecy obviously would be widespread, and thus, it is important that it be tested and evaluated. Therefore, he develops criteria to judge its authenticity (Overholt 1989: 169). First, it never stand alone. It is either preceded by something or followed by something, which somehow completes it. Secondly, it conforms to past revelations. Hall, like Ramsay, believes that God is true and does not contradict himself. And finally, he asserts that prophecy expresses love, because God is loving (Overholt 1989: 169). Overholt finds in Hall's second criteria support for his concept of the feedback sequence, because Hall asserts that not only must the prophet be called by God, but he "must be recognized by the body itself for who he is" (Overholt 1989: 169). While Hall's concept of prophecy includes such phenomenon as speaking in tongues, which obviously cannot be an element of written prophecy, his focus on the democratic nature of prophecy is quite modern, and according to Overholt it is related to his conviction that the crisis situation which precipitates prophecy can be personal as well as social (1989: 170). This fits neatly with the second characteristic of modern prophecy in the proposed theory. Furthermore, Hall's criteria that God's prophecy will be both consistently true and loving bears some resemblance to the bi-polar character of charisma proposed in this thesis.

Overholt turns next to examine the written prophecy of David Wilkerson, contained in a book published in 1981 entitled The Vision. Here it is interesting to note that he sees the possibility that in the modern age, "prophetic activity may not conform to the main biblical stereotypes of such action by standing before live audiences and speaking in God's name ... They may write books instead" (Overholt 1989: 170). This nicely reinforces the concept of written prophecy so important to the proposed model.

Although Overholt finds all the elements of his model in Wilkerson's book, the key, as he has pointed out, is audience feedback. This he discovers in Wilkerson's reference to "his closest friends and associates" advice not to publish the book. Additionally, he finds evidence of an audience or the anticipation of one in some of Wilkerson's appeals in the book: "many praying people now share this very same vision, ... and, God gave me a very special message of hope for all true believers" (Overholt 1989: 171). This, however, stretches the concept of audience far beyond its origins in oral prophecy. The word audience specifically refers to pronouncements being heard, and implies that the prophet and the people are present simultaneously to each other. Furthermore, by seeking to find evidence of oral prophecy 
when the revelation occurs in written form, is to be potentially blind to the unique characteristics of written prophecy itself.

With written prophecy, the evaluation of its content takes on much greater importance than it does when prophecy is oral. The criteria of each of them are quite different. While the proposed Model asks whether the message is particularistic or universalistic, Overholt touches on a somewhat similar distinction when he says: "To accept Wilkerson's vision leads to abandoning the world and absolutizing social and religious divisions. By contrast, to accept Ramsay's notion of prophecy leads to creative efforts to transform the world that are inclusive in their intentions" (Overholt 1989c: 173).

\section{Evaluation}

Overholt's major contribution to our understanding of prophecy is his focus on the social process of intermediation. ${ }^{14}$ This is in keeping with the sociological focus of the present work. However, while he has attempted to construct a cross-cultural model of prophecy, he has neglected to take into account the tremendous structural and symbolic differences between traditional and modern societies in which the intermediation takes place. While he is quite aware of the importance of conceptualizing intermediation as a social process, he has not utilized the sociological perspective which could give his insight more power. Thus, his model is one dimensional and static. In his model prophecy contains the same components and develops through a similar process in any age or any place, ignoring the fact that all human institutions are imbedded in history and are subject to change. In the sociological investigation of prophecy both time and place become variables which can affect the structure and process of prophetic activity. In the manipulation of these variables, instead of a single process, the muti-dimensional and dynamic quality of prophecy is seen. Because in sociology the focus is on the context of an action as well as on the action itself, within it, it is possible to identify new patterns of action in response to the perennial existential questions of human life.

This review of Overholt and others interested in understanding prophecy in the modern age has been useful, because by it each author is seen to provide separate evidence that prophecy today deviates in some way from its traditional form. It is significant that each

\footnotetext{
${ }^{14}$ The term intermediation refers to the pivotal role of the prophet in translating and communicating the extraordinary to human kind.
} 
of these deviations can be explained by the general model of prophecy presented here. First, they all affirm the possibility of modern prophecy. Then each specifically identifies some particular characteristic of prophecy key to the model. Tucker, for instance, acknowledges the problematic nature of individual prophecy in the present age. However, in locating it in the institution of the church its radical quality is constrained. Ramsay, in choosing to discuss four prophets, who were primarily writers, inadvertently points to the importance of written prophecy; and while he provides criteria for judging such prophecy, he realizes that ultimately it is the individual who must reflectively decide which "call" to heed. Hall introduces the idea that prophecy can emerge in and resolve personal crises rather than social ones, and also the concept that the charismatic call must be loving and good, as well as true. While he is not explicit that prophecy could be written, his general discussion of it does not rule it out. And finally, Overholt himself recognizes that the modern prophet may choose to write rather than to speak.

\section{Written Prophecy}

What makes the new model compelling is the fact that it provides an integrated interpretation of all these particular empirical observations. It does what Sontag suggests must be done, if we are to understand how we may hear God in the current age. In "Words of Silence: The Context of God," he says that we "... need to discover in our time the context within which God may be heard in new ways, in fresh words and with contemporary power" (Sontag 1987: 128). This paper, by articulating a new structure of prophecy, has attempted to do just that, through the discovery of the form by which modern individuals may discover God.

By developing a model to explain a genuinely modern religious movement, obviously, if the model is valid, other genuinely modern religious movements ought to develop along a similar pattern. Thus, it would be very interesting to apply this model to the numerous new religious movements which have emerged in contemporary Western society.

Neopaganism is an interesting case in point. What is intriguing about this movement is its written origins. According to Jencson, the dissemination and availability of anthropological literature has made a significant contribution to the recent revival of Neopaganism. She reports that "her research reveals a century-old process in which those researching and writing about magical practices have served to 
spread those very practices among their own informants, and via the printed page to new generations of practitioners" (Jencson 1989: 3).

In many ways modern witchcraft could be called a "book religion." Books are central to both the recruitment process and the ritualistic aspects of the religion. She writes that

A common feature in the life stories of American witches is that the concepts of the belief system are first contacted on the library shelf, not through active proselytization nor through any type of face-to-face contact with practicing witches themselves (Jencson 1989: 4).

\section{And furthermore,}

Books play such an important role that in one ritual I attended, a witch carried Inanna Queen of Heaven and Earth by Volkstein and Kramer (1983) into a sacred ritual circle and placed it on the alter. At the appropriate ritual moment he invoked the ancient Sumerian goddess by reading an ancient prayer to her from the book, much as a Christian priest would read from his Bible (Jencson, 1989:4).

While it is not clear what a detailed examination of Neopaganism in light of the new model of prophecy would reveal, it is fascinating to discover that, even in the revival of the magical world of paganism, charismatic authority is now located in the written word. This fact lends credence to the new model and suggest that further investigation of this movement within the framework of it would be fruitful.

It is also worth noting that two of the most influential non-religious movements of the modern era, Marxism and Freudianism, have been spread primarily through the authority of the written word and not through the personal charisma of either Marx or Freud. Investigating them within the framework of the proposed model might give new insights into the strengths and weakness of these movements and point out their long term prospects. Furthermore by broadening the concepts of both charisma and prophecy, it may be possible to use this model to understand other book religions and how both charisma and prophecy operate within them. Obviously there may be other uses of the model which could be developed, and hopefully in the future others will take up the challenge to test its validity and to discover new applications for it. 


\section{References}

Beckford, James A., and Thomas Luckmann (eds.)

1989 The Changing Face of Religion. London: Sage. (SAGE Studies in In-

Bell, Daniel ternational Sociology, 37)

1977 The Return of the Sacred? The Argument on the Future of Religion. British Journal of Sociology 28: 419-449.

Berger, Peter L.

1963 The Invitation to Sociology: A Humanistic Perspective. Garden City: Anchor Books.

Cross, F. L. (ed.)

1957 The Oxford Dictionary of the Christian Church. London: Oxford University Press.

Graham, William A.

1987 Beyond the Written Word: Oral Aspects of Scripture in the History of Religion. Cambridge: Cambridge University Press.

Jencson, Linda

1989 Neopaganism and the Great Mother Goddess. Anthropology Today $5 / 2: 2-4$.

\section{Luckmann, Thomas}

1967 The Invisible Religion: The Problem of Religion in Modern Society. New York: Macmillian.

\section{McCaig, A.}

1979 The Book of the Covenant. In: Geoffrey W. Bromiley (ed.), The International Standard Bible Encyclopedia; vol. 1; pp. 795-797. Grand Rapids: Eerdmans.

McGuire, Meredith $\mathbb{B}$.

1987 Religion: The Social Context. Belmont: Wadsworth.

Mommsen, Wolfgang J.

1974 The Age of Bureaucracy: Perspectives on the Political Sociology. New York: Harper Torchbooks.

Neuhaus, Richard John

1989 When Bad Things Happen to Good Religion. National Review 41: 5254.

Neumann, Franz

1962 Anxiety and Politics. In: Eric and Mary Josephson (eds.), Man Alone: Alienation in Modern Society. New York: Dell.

Overholt, Thomas W.

1989 Channels of Prophecy: The Social Dynamics of Prophetic Activity. Minneapolis: Fortress Press.

Parsons, Talcott

1968 The Structure of Social Action: A Study in Social Theory with Special Reference to a Group of Recent European Writers; vol. 2. New York: The Free Press.

1982 On Institutions and Social Evolution: Selected Writings. Chicago: University of Chicago Press. 
Ramsay, William M.

1986 Four Modern Prophets. Atlanta: John Knox Press.

Rieff, Phillip

1968 The Triumph of the Therapeutic: Uses of Faith after Freud. New York: Harper \& Row.

Sawyer, John F. A.

1987 Prophecy and Prophets of the Old Testament. London: Oxford University Press

Sontag, Frederick

1987 Words of Silence: The Context of God. In: Robert P. Scharlemann and Gilbert E. M. Ogutu (eds.), God in Language; pp. 128-146. New York: Paragon House Publishers.

Stark, Rodney, and William Sims Bainbridge

1985 The Future of Religion: Secularization, Revival, and Cult Formation. Berkley: University of California Press.

Swedemborg, Emanuel

1998 Arcana Coelestia; vol. 4. West Chester: Swedenborg Foundation.

Thompson, eJ. Arthur

1979 Covenant (OT). In: Geoffrey W. Bromiley (ed.), The International Standard Bible Encyclopedia; vol. 1; pp. 790-793. Grand Rapids: Eerdmans.

Wolkstein, Diane, and Samuel Noah Kramer

1983 Inanna: Queen of Heaven and Earth: Her Stories and Hymns from Sumer. New York: Harper \& Row.

Wallace, Anthony $\mathbb{F}$. C.

1966 Religion: An Anthropological View. New York: Random House.

Wilson, Bryan

1976 Contemporary Transformations of Religion. Oxford: Oxford University Press.

Weber, Max

1958a From Max Weber: Essays in Sociology. Ed. by H. H. Gerth, and C. Wright Mills. New York: Oxford University Press.

1958b The Protestant Ethic and the Spirit of Capitalism. New York: Schribner's Sons.

1964 The Sociology of Religion. Boston: Beacon Press.

Webster

1958 Webster's New Collegiate Dictionary. Springfield: Merriam.

Williams-Hogan, Jane

1985 The New Church in a Disenchanted World: A Study of the Formation and Development of the General Conference of the New Church. Ann Arbor, MI: University Microfilms International.

1990 Charisma in the Modern World: A New Theory of Religious Action. [unpubl. Development Thesis, Bryn Athyn College of the New Church] 